\title{
4: 1762854-1777829
}

National Cancer Institute

\section{Source}

National Cancer Institute. 4:1762854-1777829. NCI Thesaurus. Code C42272.

Physical location of FGFR3_Gene 